\title{
Surface and bulk properties of dental resin-composites after solvent storage
}

DOI:

10.1016/j.dental.2016.05.007

\section{Document Version}

Accepted author manuscript

Link to publication record in Manchester Research Explorer

\section{Citation for published version (APA):}

Al Sunbul, H., Silikas, N., \& Watts, D. (2016). Surface and bulk properties of dental resin-composites after solvent storage. Dental Materials, 32(8). https://doi.org/10.1016/j.dental.2016.05.007

\section{Published in:}

Dental Materials

\section{Citing this paper}

Please note that where the full-text provided on Manchester Research Explorer is the Author Accepted Manuscript or Proof version this may differ from the final Published version. If citing, it is advised that you check and use the publisher's definitive version.

\section{General rights}

Copyright and moral rights for the publications made accessible in the Research Explorer are retained by the authors and/or other copyright owners and it is a condition of accessing publications that users recognise and abide by the legal requirements associated with these rights.

\section{Takedown policy}

If you believe that this document breaches copyright please refer to the University of Manchester's Takedown Procedures [http://man.ac.uk/04Y6Bo] or contact uml.scholarlycommunications@manchester.ac.uk providing relevant details, so we can investigate your claim.

\section{OPEN ACCESS}




\title{
Surface and bulk properties of dental resin- composites after solvent storage
}

\author{
Hanan Al Sunbul ${ }^{a, b}$, Nick Silikas ${ }^{a, *}$, David C. Watts ${ }^{a, c}$ \\ a Biomaterials Science Research Group, School of Dentistry, University of Manchester, United Kingdom \\ b College of Dentistry, King Saud University, Riyadh, Saudi Arabia \\ c Photon Science Institute, University of Manchester, United Kingdom
}

\section{A R T I C L E I N F O}

\section{Article history:}

Received 10 September 2015

Received in revised form

11 May 2016

Accepted 13 May 2016

Available online $\mathrm{xxx}$

\section{Keywords:}

Resin-composite

Bulk-fill

Solvents

Micro-hardness

Diametral tensile strength

\begin{abstract}
A B S T R A C T
Objectives. To investigate the surface micro-hardness and the diametral tensile strength (DTS) of bulk-fill and conventional resin-composites after storage in food simulating solvents.

Methods. Eight materials were investigated. For the micro-hardness measurement, Teflon mould with an internal dimensions of $10 \mathrm{~mm}$ and $2 \mathrm{~mm}(n=15)$. For the DTS measurement, Split stainless steel moulds were used to make disk-shaped specimens of $6 \mathrm{~mm}$ diameter and $2 \mathrm{~mm}$ thickness $(n=15)$. Materials were subdivided in to three groups (water, $75 \%$ ethanol/water and MEK). Micro-hardness measurements were made under a load of $300 \mathrm{gm}$ with a dwell time of $15 \mathrm{~s}$ at 7, 30, and 90ds after storage. DTS was measured after 30ds at a cross head speed of $0.5 \mathrm{~mm} / \mathrm{min}$.

Results. The storage time and type of solvent had a significant influence on the microhardness. MEK showed more drastic reduction in the material micro-hardness with an exception of G-aenial universal flo (GA-F) which showed similar results in water/ethanol and MEK. DTS values of materials stored in water ranged from 48.7 MPa for the GA-F and 30.6 MPa for Ever X posterior (EXP). Generally, the results are observed to decrease with increasing solvent power, except for GA-F.

Significance. Bulk-fill materials showed no superior results compared with the other materials. For the bulk-fill materials that are designed to be used as a base, their penetration by the solvents may be shielded and thus the changes observed in this study may not be of clinical importance.
\end{abstract}

๑ 2016 The Academy of Dental Materials. Published by Elsevier Ltd. All rights reserved.

\section{Introduction}

The continuous development of resin-composite materials aims for long lasting aesthetic dental restorations. There is a large range of available resin-composites, generalisation about their behaviour and performance should be made cautiously, many resin-composite materials still have their own shortcoming in clinical performance [1]. Resin-composite restorations must survive an aggressive environment that varies from patient to patient as do the masticatory forces, occlusal habits, abrasive foods, chemically active foods and liquids, temperature fluctuations, humidity variations, bacterial products, and salivary enzymes. These factors, separately

\footnotetext{
* Corresponding author at: School of Dentistry, The University of Manchester, Manchester M13 9PL, UK. Tel.: +441612756747.

E-mail address: nick.silikas@manchester.ac.uk (N. Silikas).

http://dx.doi.org/10.1016/j.dental.2016.05.007

0109-5641/@ 2016 The Academy of Dental Materials. Published by Elsevier Ltd. All rights reserved.
} 
or collectively, determine the longevity of the restoration [1-6]. From a material aspect, the performance of the resincomposite restoration depends on several factors including the monomer system, the filler type, filler loading and the extent of cure [7].

Degradation of resin-composite restorations in the oral environment can be simulated by the use of different food simulating solvents which are known to cause different effects on the mechanical properties of the restoration and its longevity [4,8-10]. Similar polarity of a particular solvent and a substance will tend to make them mutually soluble, different polarity on the other hand will make the solubility difficult $[11,12]$. The effect of solvents on resin-composites is determined by their solubility parameter and the nature of their monomer. The solubility parameter is important in terms of its similarity to that of other substance [10].

The solubility parameter is defined as the square root of the cohesive energy density of the solvent; it is a mean of predicting the ability of a solvent to dissolve a substance (Eq. 5-1). It provides a clear numerical way of predicting the extent of interaction between materials. Solubility parameter is expressed as $\delta / \mathrm{MPa}^{1 / 2}[11,12]$. Water is known to be used as an aging media in several studies [10,13-15], ethanol and Methyl ethyl ketone (MEK) are known to represent food simulating solvents and cause an extreme dietary effect.

$\delta=\sqrt{c}=\left[\frac{\Delta H-R T}{V m}\right]^{1 / 2}$

c: cohesive energy density, $\Delta \mathrm{H}$ : heat of vaporisation, $\mathrm{Vm}$ : molar volume, R: gas constant and $\mathrm{T}$ : temperature.

In the chemical degradation theory, the chemical components of food and saliva may be absorbed by the resin matrix, resulting in softening and surface destruction [16]. Degradation of fillers could also be a potential problem regarding durability and marginal integrity as it may cause de-bonding from the material [17-19]. Clinical performance of resin-composite materials is determined by their mechanical properties including their fracture toughness, flexural strength, compressive strength, diametral tensile strength, surface hardness and wear resistance $[5,20]$. Failure of resincomposite restorations is commonly represented by fracture of the restoration, tooth fracture, marginal fracture, discolorations, marginal staining and secondary caries [1].

Surface hardness is a surface property that is defined as the resistance of the material surface to indentation [21]. Measuring the surface hardness can give an indication of the degree of conversion and consequently the clinical performance of resin-composite material after aging in food simulating solvents [22,23]. Furthermore, Dental restorations are expected to withstand tensile stresses from oblique or transverse masticatory functional loading, therefore tensile strength is an important property for any dental material [24]. Since resincomposites are relatively brittle under conventional loading rates, they would be expected to fail under tensile stresses during mastication. For this reason, the tensile strength of these materials may be considered to have more clinical relevance than the compressive strength [25].

Recently available resin-composites incorporate a range of monomer systems that may respond differently to aqueous and non-aqueous solvents as present in food materials. For a given matrix, the most likely effect of a solvent is to decrease its mechanical properties $[18,26]$ nevertheless, hardness of resin-composites have been shown to progressively increase over a period of time of at least $30 \mathrm{ds}$. Therefore, it is possible that some opposing trends could be operating during the period of solvent storage: first, the softening effect of the solvent and secondly the hardening effect due to the elevated degree of conversion [27-30].

The effect of the food simulating solvents is one aspect of simulation of the oral environment. Therefore, the objectives of the present study was to investigate the effect of three solvents (de-ionized water, 75\% Ethanol/water and MEK) on the surface micro-hardness and diametral tensile strength of eight commercially available resin-composite materials. In this study, the null hypotheses were

1) There is no significant difference between the examined materials with the regards to their surface micro-hardness and DTS,

2) Different solvents provoke the same effect on different materials (on surface micro-hardness and DTS) and

3) There is no significant difference between the aging durations on the surface micro-hardness of the examined materials.

\section{Materials and method}

Eight resin-composite materials were investigated (Table 1). There were four bulk-fill, two nano-hybrid and two microhybrid resin-composites.

\subsection{Materials and method}

Eight resin-composite materials were investigated (Table 1). There were four bulk-fill, two nano-hybrid and two microhybrid resin-composites.

\subsection{Surface micro-hardness}

120 disk-shaped specimens were produced according the manufacturers' instructions. 15 specimens were made for each material using a Teflon mould with an internal diameter of $10 \mathrm{~mm}$ and $2 \mathrm{~mm}$ thickness. The specimens were made carefully, to avoid any air entrapment during placement of the uncured material. The specimens were fabricated at a room temperature of $23 \pm 1^{\circ} \mathrm{C}$ and a relative humidity of $50 \pm 2 \%$. The mould was sandwiched between two polyester films and microscopic slides ( $1 \mathrm{~mm}$ thickness) on each side. The curing was made for $20 \mathrm{~s}$ at an output irradiance of $1200 \mathrm{~mW} / \mathrm{cm}^{2}$ using an Elipar S10 LED curing light from $3 \mathrm{M}$ ESPE. The light output was measured using a laboratory grade NISTreferenced USB-4000 spectrometer (MARC Resin Calibrator v.3, Blue-light analytics Inc, Halifax, NS, Canada). The specimens were irradiated from top and bottom surfaces. The specimens were finished to remove any irregularities using 1000 grit abrasive papers.

Immediately after polymerization, the specimens were stored in an oven at a $37 \pm 1^{\circ} \mathrm{C}$ for $24 \mathrm{~h}$. The baseline 


\begin{tabular}{|c|c|c|c|c|c|}
\hline Material Material cod & Batch no. & Filler loading & Organic matrix & Manufacturer & Type \\
\hline Smart Dentin Replacement (SDR) & 10211 & $44 \% \mathrm{vol}$ & $\begin{array}{l}\text { Modified UDMA, } \\
\text { BIS-EMA, } \\
\text { TEGDMA }\end{array}$ & $\begin{array}{l}\text { Dentsply Caulk, } \\
\text { Milford, } \\
\text { Delaware, USA }\end{array}$ & $\begin{array}{l}\text { Fluoride- } \\
\text { containing } \\
\text { Flowable BF }\end{array}$ \\
\hline Venus bulk Fill (V-BF) & 010101 & $38 \% \mathrm{vol}$ & UDMA, BIS-EMA & $\begin{array}{l}\text { Heraeus Kulzer } \\
\text { GmbH, Germany }\end{array}$ & $\begin{array}{l}\text { Nano-hybrid } \\
\text { Flowable BF }\end{array}$ \\
\hline Tetric Evoceram (TEC) & 503461 & $53-55 \%$ vol & $\begin{array}{l}\text { Bis-GMA, UDMA, } \\
\text { BIS-EMA }\end{array}$ & $\begin{array}{l}\text { Ivoclar Vivadent, } \\
\text { Schaan, } \\
\text { Liechtenstein }\end{array}$ & $\begin{array}{l}\text { Nano-hybrid } \\
\text { conventional }\end{array}$ \\
\hline Tetric Evoceram Bulk fill (TEC- BF) & R82387 & $60-61 \%$ vol & $\begin{array}{l}\text { Bis-GMA, UDMA } \\
\text { BIS-EMA }\end{array}$ & $\begin{array}{l}\text { Ivoclar Vivadent, } \\
\text { Schaan, } \\
\text { Liechtenstein }\end{array}$ & $\begin{array}{l}\text { Nano-hybrid } \\
\text { Packable BF }\end{array}$ \\
\hline Ever X Posterior (EVX) & 1301292 & $57 \%$ vol & $\begin{array}{l}\text { Bis-GMA, } \\
\text { TEGMA,PMMA }\end{array}$ & $\begin{array}{l}\text { GC Corporation, } \\
\text { Tokyo, Japan }\end{array}$ & $\begin{array}{l}\text { Fibre-reinforced } \\
\text { Packable BF }\end{array}$ \\
\hline G-aenial Universal flow (GA-F) & 1011091 & $50 \% \mathrm{vol}$ & $\begin{array}{l}\text { Bis-GMA free, } \\
\text { UDMA Bis-MePP, } \\
\text { TEGMA }\end{array}$ & $\begin{array}{l}\text { GC Corporation, } \\
\text { Tokyo, Japan }\end{array}$ & $\begin{array}{l}\text { Nano-hybrid } \\
\text { Flowable }\end{array}$ \\
\hline G-aenial Anterior (GA-A) & 1306051 & $63 \% \mathrm{vol}$ & $\begin{array}{l}\text { Bis-GMA free. } \\
\text { UDMA, } \\
\text { dimethacrylate }\end{array}$ & $\begin{array}{l}\text { GC Corporation, } \\
\text { Tokyo, Japan }\end{array}$ & $\begin{array}{l}\text { Micro-hybrid } \\
\text { conventional }\end{array}$ \\
\hline G-aenial Posterior (GA-P) & 1308222 & $65 \%$ vol & $\begin{array}{l}\text { Bis-GMA free. } \\
\text { UDMA, } \\
\text { dimethacrylate }\end{array}$ & $\begin{array}{l}\text { GC Corporation, } \\
\text { Tokyo, Japan }\end{array}$ & $\begin{array}{l}\text { Micro-hybrid } \\
\text { conventional }\end{array}$ \\
\hline
\end{tabular}

surface micro-hardness measurements (24h) were taken using a Vickers Micro-hardness Tester (FM-700, Kawasaki, Kanagawa, Japan) with a diamond pyramid micro-indenter. The measurement was conducted at room temperature $\left(23^{\circ} \mathrm{C}\right)$ under a load of $300 \mathrm{gm}$ with a dwell time of $15 \mathrm{~s}$. Five indentations, $1 \mathrm{~mm}$ apart from the specimen margins and from each other, were made and averaged to yield a single microhardness number (VHN). The specimens were then randomly assigned to one of the three storage media; de-ionized water, 75\% ethanol/water, methyl ethyl ketone (MEK). The specimens were immersed and stored in $10 \mathrm{~mL}$ of the media at $37 \pm 1^{\circ} \mathrm{C}$ in individual glass vials. The Specimens were kept under the same conditions for the subsequent measurements at 7, 30, $90 \mathrm{ds}$.

\subsection{Diametral tensile strength}

120 disk-shaped specimens were produced according to the manufacturers' instructions. Split stainless steel moulds were used to make disk-shaped specimens of $6 \mathrm{~mm}$ diameter and $2 \mathrm{~mm}$ thickness $(n=15)$.

Material was placed in the mould between two polyester films and microscopic slides ( $1 \mathrm{~mm}$ thickness) and cured from both sides for $20 \mathrm{~s}$ by an Elipar S10 LED curing light from $3 \mathrm{M}$ ESPE $\left(1200 \mathrm{~mW} / \mathrm{cm}^{2}\right)$. The light output was verified using a laboratory grade NIST-referenced USB-4000 spectrometer (MARC Rsin Calibrator v.3, Blue-light analytics Inc, Halifax, NS, Canada). Specimens were carefully removed by unscrewing the split mould and were subsequently finished to remove any irregularities using 1000 grit abrasive papers. Specimens were randomly assigned to one of the three storage groups; de-ionized water, 75\% ethanol/water, methyl ethyl ketone (MEK). Each specimen was placed in a glass vials with $10 \mathrm{ml}$ of the storage media and stored in an incubator at $37^{\circ} \mathrm{C}$ for $30 \mathrm{ds}$. After the storage period specimens were taken out of the storage media and blot dried carefully. Diametral Tensile Strength (DTS) was measured with a universal testing machine (Zwick/Roell Z020, Leominster, UK) at a cross head speed of $0.5 \mathrm{~mm} / \mathrm{min}$. The DTS value in MPa was calculated using the following Eq. [25]

$\mathrm{DTS}=\frac{2 F}{\pi d t}$

where $F$ is the maximum force applied to failure $(\mathrm{N}), d$ is the diameter $(6 \mathrm{~mm})$ and $t$ is the thickness $(2 \mathrm{~mm})$.

\subsection{Statistical analysis}

Using SPSS (Version 20.0, IBM, New York, USA), data were analysed using three way ANOVA to investigate the interaction between the dependent variable (VHN) and the independent variables (materials, the solvents and storage times) and one way ANOVA. Data were analysed for equal variances using Levene's test of homogeneity of variance $(p<0.05)$. Following the assumption of equal variance, Tukey's post-hoc test was done to establish homogenous subsets at $(p<0.05)$. Data for the DTS values were analysed using two-way ANOVA to investigate the interaction between the dependent variable (DTS) and the independent variables (materials and solvents) and One-way ANOVA followed by Tukey's post-hoc tests $(p<0.05)$ after the assumption of equal variance. Regression analysis was made to investigate the relationship between the filler loading and the VHN and DTS of the materials. Regression analysis was carried out to investigate the relationship between the VHN and DTS values.

\section{Results}

\subsection{Surface micro-hardness}

The means and standard deviations of the VHN of the investigated materials are presented in Table 2. 
Table 2 - VHN means and standard deviations of the investigated materials measured in dry, after 7, 30, 90 ds of solvents storage.

\begin{tabular}{|c|c|c|c|c|c|c|c|c|c|c|c|c|}
\hline \multirow[t]{2}{*}{ Material } & \multicolumn{4}{|c|}{ De-ionized water } & \multicolumn{4}{|c|}{ 75\% Ethanol/Water } & \multicolumn{4}{|l|}{ MEK } \\
\hline & Dry & $7 d$ & $30 d$ & $90 d$ & Dry & $7 d$ & $30 d$ & $90 d$ & Dry & $7 d$ & $30 d$ & $90 d$ \\
\hline \multirow[t]{2}{*}{ SDR } & $33.49^{\mathrm{a}}$ & $22.45^{\mathrm{b}}$ & $20.63^{b}$ & $23.10^{\mathrm{b}}$ & $33.81^{\mathrm{a}}$ & 11.09 & $4.72^{\mathrm{d}, \mathrm{e}}$ & $4.24^{\mathrm{e}}$ & $33.18^{\mathrm{a}}$ & $4.24^{\mathrm{A}, \mathrm{e}}$ & $5.80^{\mathrm{A}, \mathrm{c}, \mathrm{d}}$ & $6.86^{\mathrm{c}}$ \\
\hline & $(1.7)$ & $(1.1)$ & $(2.8)$ & $(1.7)$ & (1.4) & $(1.9)$ & $(0.8)$ & $(0.4)$ & $(1.3)$ & $(0.5)$ & $(1.2)$ & $(1.5)$ \\
\hline \multirow[t]{2}{*}{$\mathrm{V}-\mathrm{BF}$} & $22.65^{a}$ & 13.71 & 15.08 & 19.73 & $22.6^{\mathrm{a}}$ & $6.31^{b}$ & $6.29^{\mathrm{b}}$ & 11.29 & $22.72^{\mathrm{a}}$ & $5.54^{\mathrm{A}, \mathrm{b}}$ & $6.12^{\mathrm{A}, \mathrm{b}}$ & 9.66 \\
\hline & $(1.2)$ & $(0.9)$ & $(1.2)$ & (1.8) & $(0.8)$ & $(0.5)$ & $(0.6)$ & $(1.3)$ & $(1.2)$ & $(0.4)$ & $(1.1)$ & $(1.0)$ \\
\hline \multirow[t]{2}{*}{ TEC } & $48.37^{\mathrm{A}, \mathrm{a}, \mathrm{c}}$ & $35.27^{\mathrm{A}, \mathrm{b}}$ & $34.87^{\mathrm{A}, \mathrm{b}}$ & $34.90^{\mathrm{b}}$ & $48.38^{\mathrm{A}, \mathrm{a}, \mathrm{c}}$ & $29.51^{c}$ & 26.81 & $22.13^{\mathrm{d}, \mathrm{e}}$ & $48.30^{\mathrm{A}, \mathrm{a}}$ & $23.07^{d}$ & $20.68^{\mathrm{B}, \mathrm{e}}$ & $20.75^{\mathrm{A}, \mathrm{e}}$ \\
\hline & $(0.6)$ & $(5.2)$ & $(2.1)$ & $(2.6)$ & $(1.0)$ & $(3.0)$ & $(2.0)$ & $(1.6)$ & $(0.7)$ & (2.4) & $(0.6)$ & (1.4) \\
\hline \multirow[t]{2}{*}{ TEC-BF } & $48.07^{\mathrm{A}, \mathrm{a}}$ & $37.22^{\mathrm{A}, \mathrm{b}}$ & $34.88^{\mathrm{A}, \mathrm{b}}$ & $41.00^{\mathrm{A}, \mathrm{B}}$ & $50.56^{\mathrm{B}, \mathrm{a}}$ & $21.28^{\mathrm{A}, \mathrm{C}}$ & $19.52^{\mathrm{A}, \mathrm{C}}$ & $29.76^{\mathrm{A}}$ & $48.96^{\mathrm{A}, \mathrm{a}}$ & $21.47^{c}$ & $20.96^{\mathrm{B}, \mathrm{C}}$ & $24.97^{\mathrm{B}}$ \\
\hline & $(5.2)$ & $(2.5)$ & $(4.4)$ & (3.1) & (2.0) & $(3.2)$ & $(2.1)$ & $(2.8)$ & $(2.9)$ & (1.9) & (1.4) & $(2.0)$ \\
\hline \multirow[t]{2}{*}{ EVX } & $61.42^{\mathrm{a}}$ & $42.17^{b}$ & $40.70^{\mathrm{B}, \mathrm{b}}$ & $43.06^{\mathrm{A}, \mathrm{b}}$ & $59.81^{a}$ & $24.74^{\mathrm{c}}$ & $25.07^{c}$ & $28.98^{A}$ & $57.78^{a}$ & $24.76^{c}$ & $22.96 \mathrm{~B},{ }^{\mathrm{C}}$ & $25.55^{\mathrm{B}, \mathrm{C}}$ \\
\hline & (3.8) & $(2.9)$ & $(2.8)$ & (5.0) & (3.7) & $(1.4)$ & $(2.0)$ & (3.2) & (1.8) & $(1.6)$ & $(2.0)$ & (1.5) \\
\hline \multirow[t]{2}{*}{ GA-F } & $49.01^{\mathrm{A}, \mathrm{a}}$ & $39.07^{\mathrm{B}, \mathrm{b}}$ & $39.96^{\mathrm{B}, \mathrm{b}}$ & $40.38^{\mathrm{B}, \mathrm{b}}$ & $49.02^{\mathrm{A}, \mathrm{B}, \mathrm{a}}$ & $32.86^{c}$ & $33.37^{c}$ & $24.31^{\mathrm{e}}$ & $49.05^{\mathrm{A}, \mathrm{a}}$ & $27.51^{d}$ & $25.51^{\mathrm{d}, \mathrm{e}}$ & $24.60^{\mathrm{B}, \mathrm{e}}$ \\
\hline & $(0.8)$ & $(5.3)$ & $(1.2)$ & (2.0) & $(0.8)$ & $(4.3)$ & (3.3) & $(0.8)$ & $(0.9)$ & $(1.9)$ & (1.4) & $(0.7)$ \\
\hline \multirow[t]{2}{*}{ GA-A } & $37.89^{a}$ & 30.00 & $28.13^{b}$ & $27.70^{b}$ & $38.51^{\mathrm{a}}$ & $16.62^{c}$ & $14.24^{\mathrm{d}, \mathrm{e}}$ & $14.24^{\mathrm{d}, \mathrm{e}}$ & $41.18^{\mathrm{a}}$ & $13.23^{\mathrm{e}}$ & $15.08^{\mathrm{c}, \mathrm{d}}$ & $14.60^{\mathrm{d}, \mathrm{e}}$ \\
\hline & $(2.5)$ & $(2.0)$ & $(2.5)$ & (1.6) & (2.3) & $(1.2)$ & $(1.4)$ & $(1.7)$ & (3.6) & $(0.9)$ & $(0.7)$ & $(0.8)$ \\
\hline \multirow[t]{2}{*}{ GA-P } & $47.19^{\mathrm{A}, \mathrm{a}}$ & $39.21^{\mathrm{B}, \mathrm{b}}$ & $34.83^{\mathrm{A}}$ & $39.24^{\mathrm{B}, \mathrm{b}}$ & $46.46^{\mathrm{a}}$ & $20.04^{\mathrm{A}, \mathrm{c}, \mathrm{d}}$ & $18.74^{\mathrm{A}, \mathrm{d}}$ & $19.91^{\mathrm{c}, \mathrm{d}}$ & $45.80^{\mathrm{a}}$ & $19.67^{\mathrm{c}, \mathrm{d}}$ & $18.34^{\mathrm{d}}$ & $20.66^{\mathrm{A}, \mathrm{C}}$ \\
\hline & (2.4) & (3.3) & $(2.2)$ & $(2.8)$ & (1.9) & (1.8) & $(1.4)$ & (1.4) & $(2.4)$ & (1.4) & $(1.2)$ & $(1.0)$ \\
\hline & & & & & & & $<0.05)$ & & & & & \\
\hline & n & apital le & & & & & & & & & & \\
\hline
\end{tabular}

The interaction between the resin-composite materials, solvents and storage times was statistically significant $(p<0.0005)$. VHN of the material after $24 \mathrm{~h}$ of curing ranged from 22.65 (1.2) for V-BF to 61.42 (3.8) for EVX. After the final aging period (90d), VHN ranged from 4.24 (0.4) for SDR to 29.76 (2.8) for TEC-BF in 75\% Ethanol/water and from 6.86 (1.5) for SDR to 25.55 (1.5) for EVX in MEK (Fig. 1).

The aging period had a significant influence on VHN; the baseline values were significantly higher compared to the other subsequent values measured over the different periods of time $(p<0.05)$. The reduction in VHN, in $75 \%$ ethanol/water stored specimens, ranged from $38 \%$ for TEC-BF to $87 \%$ for SDR (Fig. 2). On the other hand, the MEK stored specimens, the reduction ranged from $49 \%$ for TEC-BF to $79 \%$ for SDR (Figs. 3-11).

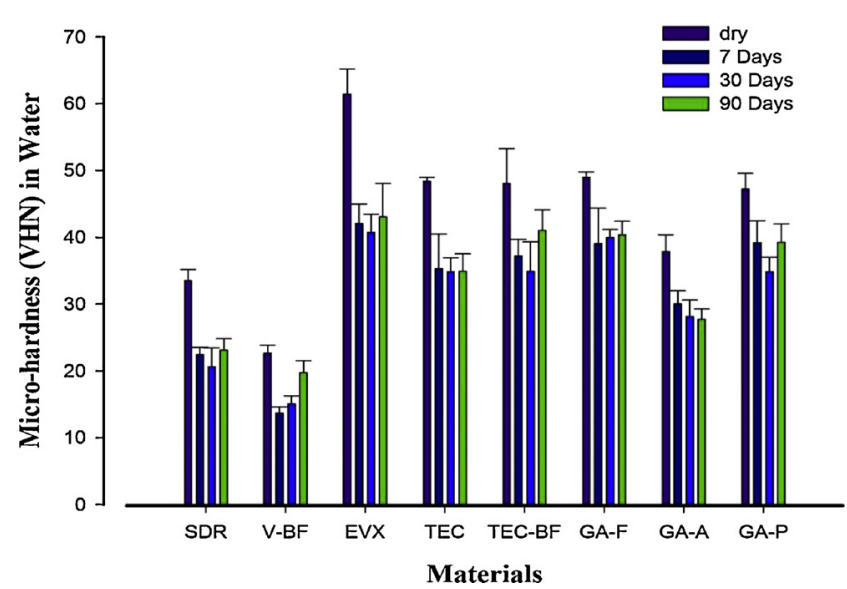

Fig. 1 - Means and standard deviations of the VHN in water.
V-BF, TEC, TEC-BF, EVX and GA-A showed more drastic VHN reduction in MEK stored specimens compared to $75 \%$ Ethanol/water stored specimens. GA-F showed no significant difference in the amount of reduction in both solvents $50 \%$. SDR and GA-P showed more surface degradation with $75 \%$ Ethanol/water solvent ( $87 \%-57 \%$, respectively) compared to MEK stored specimens (79\%-55\%, respectively) Fig. 12. In analysing the relation between the VHN and the filler loading, there was a positive correlation between the filler loading and the Micro-hardness of the investigated materials $\left(r^{2}=0.72\right)$.

The VHN at 90d was plotted against the logarithmic values of the solvent solubility parameters (Fig. 12); a positive linear regression was found with all the investigated materials.

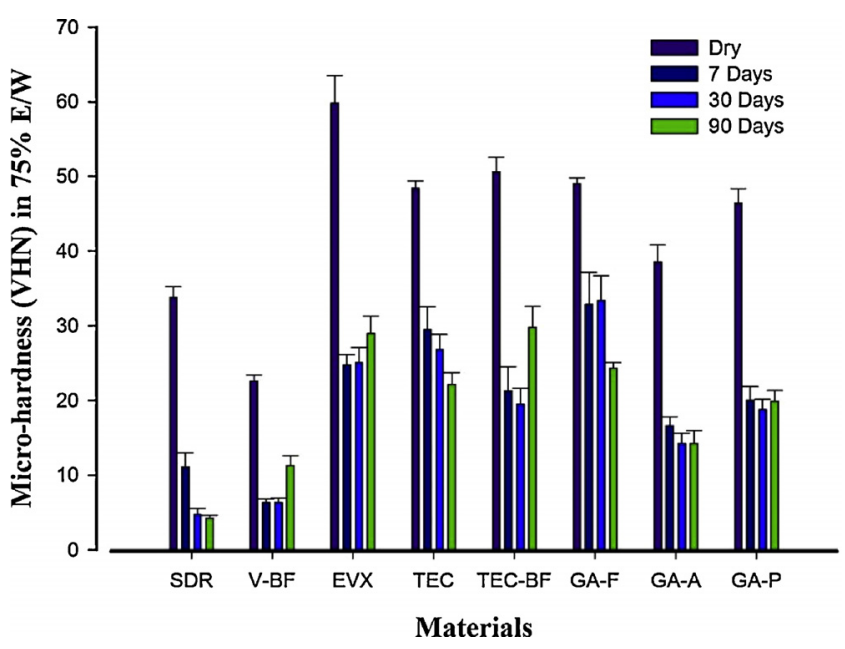

Fig. 2 - Means and standard deviations of the VHN in $75 \%$ E/W. 


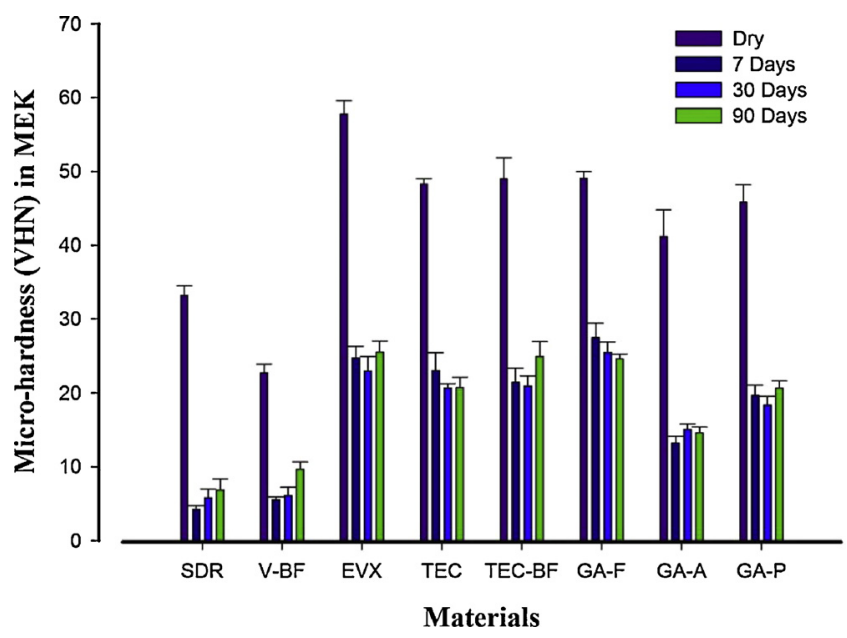

Fig. 3 - Means and standard deviations of the VHN in MEK.

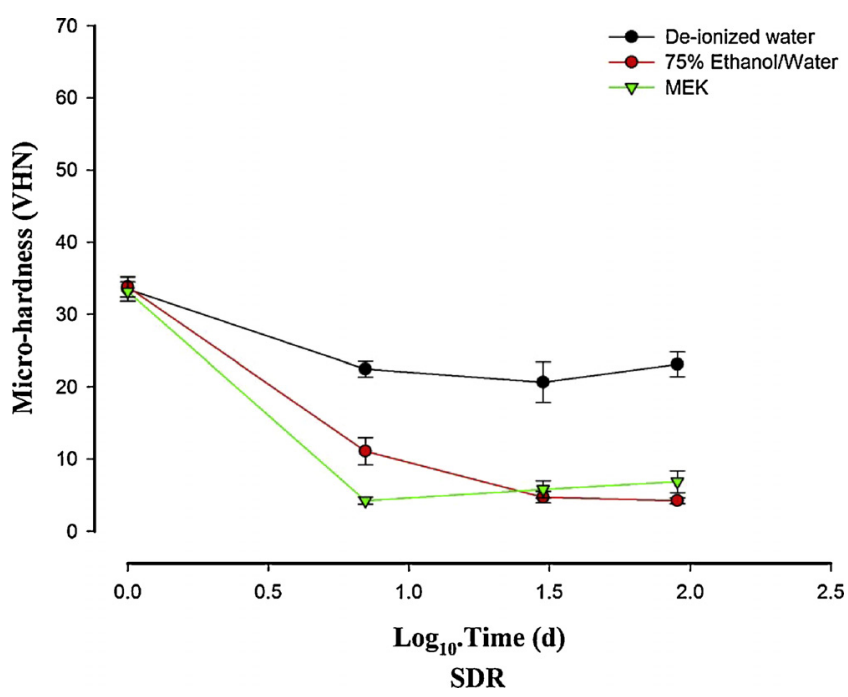

Fig. 4 - The means and standard deviations of VHN against $\log _{10}$. Time (ds) for SDR.

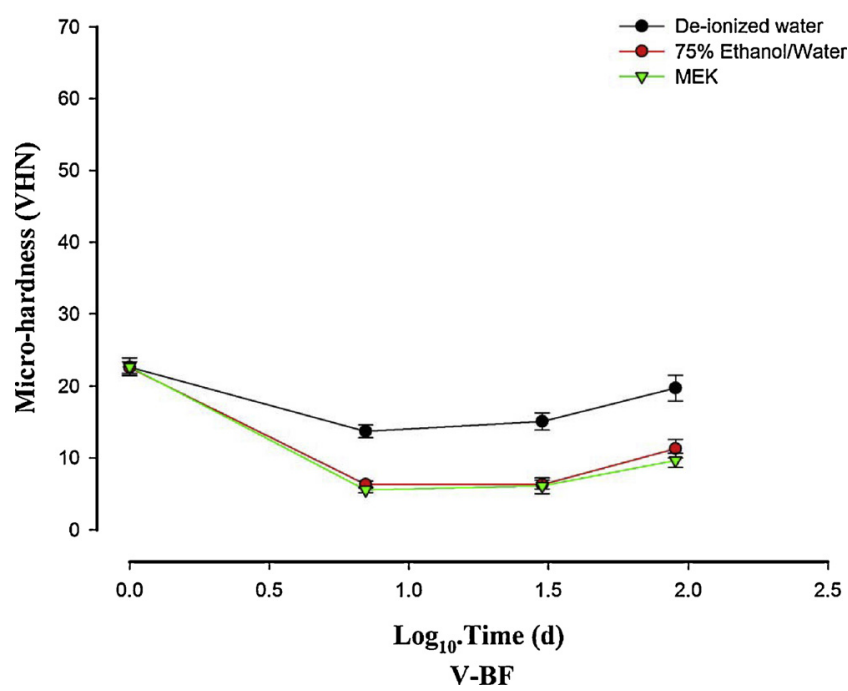

Fig. 5 - The means and standard deviations of VHN against $\log _{10}$. Time (ds) for V-BF.
Table 3 - The means and standard deviations for the

DTS values after $\mathbf{3 0}$ ds of storage in different solvents.

\begin{tabular}{llll} 
Material & \multicolumn{3}{l}{ DTS (MPa) } \\
\cline { 2 - 4 } & De-ionized water & $\begin{array}{l}\text { 75\% Ethanol/ } \\
\text { Water }\end{array}$ & MEK \\
\hline SDR & $43.22(1.81)^{\mathrm{a}, \mathrm{d}}$ & $20.40(0.81)^{\mathrm{a}, \mathrm{b}}$ & $12.06(0.50)^{\mathrm{a}, \mathrm{c}}$ \\
V-BF & $42.27(3.04)^{\mathrm{a}, \mathrm{b}, \mathrm{d}}$ & $27.20(3.01)^{\mathrm{a}, \mathrm{c}}$ & $17.20(3.14)^{\mathrm{a}, \mathrm{b}}$ \\
EVX & $30.56(4.71)^{\mathrm{c}}$ & $17.06(1.78)^{\mathrm{b}, \mathrm{A}}$ & $17.89(2.24)^{\mathrm{b}, \mathrm{A}}$ \\
TEC & $33.73(4.54)^{\mathrm{b}, \mathrm{c}}$ & $20.84(2.85)^{\mathrm{a}, \mathrm{b}}$ & $11.58(2.20)^{\mathrm{a}, \mathrm{c}}$ \\
TEC-BF & $35.05(3.00)^{\mathrm{a}, \mathrm{b}, \mathrm{c}}$ & $24.50(4.38)^{\mathrm{a}, \mathrm{b}, \mathrm{c}}$ & $19.02(0.54)^{\mathrm{b}}$ \\
GA-F & $57.14(5.66)^{\mathrm{e}, \mathrm{B}}$ & $57.06(8.02)^{\mathrm{B}}$ & $49.35(5.36)^{\mathrm{B}}$ \\
GA-A & $46.88(5.52)^{\mathrm{d}}$ & $29.76(2.09)^{\mathrm{c}, \mathrm{d}}$ & $7.98(1.64)^{\mathrm{c}}$ \\
GA-P & $48.67(4.38)^{\mathrm{d}, \mathrm{e}}$ & $37.01(5.18)^{\mathrm{d}}$ & $19.76(2.56)^{\mathrm{b}}$ \\
\hline
\end{tabular}

Materials in the same row with the same capital letter superscript indicates no significant difference $(p<0.05)$.

Materials in the same column with the same small letter superscript indicates no significant difference $(p<0.05)$.

\subsection{Diametral tensile strength}

The means and standard deviations for the DTS values after $30 \mathrm{ds}$ of storage are summarized in Table 3 and Fig. 13. There was a significant interaction between the resin-composites and the solvent type $(p<0.0005)$. Generally, the highest values were observed for the water stored materials while the lowest values were observed for the MEK-stored materials.

GA-F showed the highest value in all the three solvents. GA-A showed the highest reduction in DTS value among the other materials when stored in MEK $(7.98 \pm 1.64 \mathrm{MPa})$.

Solvent solubility showed a significant relationship with the DTS values as it was demonstrated in Fig. 14. The regression analysis showed no significant relationship between the filler loading in and the DTS values. The mode of failure remained essentially constant with a vertical (diametral) crack Fig. 15. No significant relationship was found between the VHN and the DTS values of the investigated materials Fig. 16.

\section{Discussion}

The results of this in vitro study reject the research hypotheses, supporting that the resin- composite material itself, the storage medium and the storage duration have an influence on the clinical performance and longevity of the dental resincomposite materials.

The mechanical properties of resin-composites depend primarily on their monomer system, filler loading, filler size and the filler-resin interface [7,31]. For that purpose, different materials were selected in this study to represent different categories and highlight the effects of their differences. VBF, TEC-BF, TEC and GA-F are nano-hybrid composites with different monomer systems. On the other hand, GA-A and GA-P are micro-hybrid composites with different loading percentages and UDMA-based monomer matrices. EVX is a glass fibre-reinforced material with Bis-GMA-based matrix. SDR is a fluoride containing flowable bulk-fill material based on modified UDMA matrix.

Surface micro-hardness of resin-composite materials correlates with their mechanical properties such as abrasion resistance and form stability. Additionally, micro-hardness is 


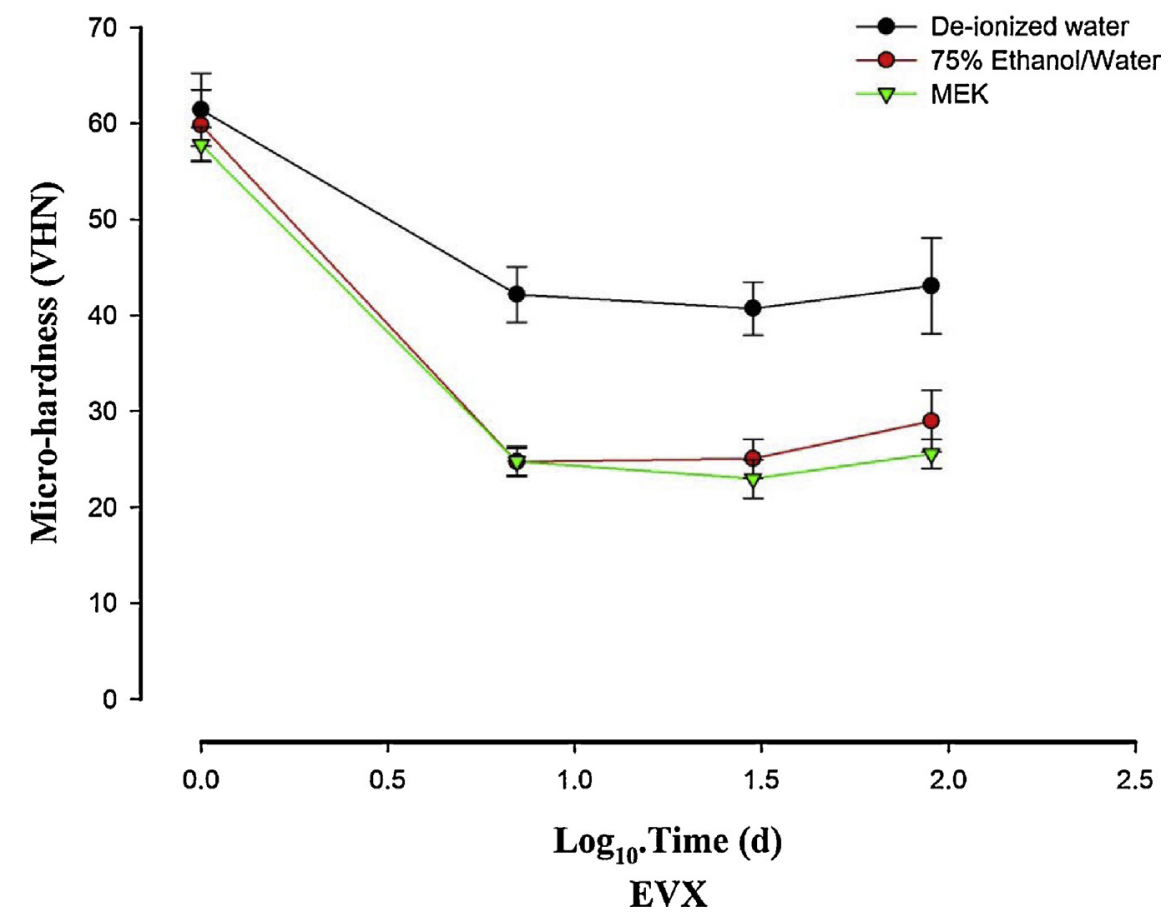

Fig. 6 - The means and standard deviations of VHN against $\log _{10}$. Time (ds) for EVX.

considered as a strong indication to the degree of conversion of the material. Accordingly, measuring the surface microhardness could be a method of determining the longevity and the service life of the direct resin-based restorations $[11,23,26,32,33]$. Top surface hardness was measured as it received the maximum irradiance from the light curing unit and to avoid the attenuation of the light by passing through the bulk of the material [34].

Tensile strength of dental restoration is considered a critical indicator of their success as material with high tensile strength is mandatory to withstand the multidirectional masticatory forces. Diametral strength measurements is a method of evaluating the tensile strength of brittle materials as it overcomes the difficulties associated with other methods [24,26].

For the purpose of simulating different oral conditions, three solvents were included in this study with increasing solvent powers. Water has been proven to cause various effects on dental resin-composites as a result of degradation process $[7,12,15,35,36]$. Ethanol and MEK are solvents of choice to simulate an accelerated ageing process. Both solvents have solubility parameters that closely match that of the resin, (e.g. PMMA $=18.6$, as a close approximation to dimethacrylates), $26.2 \delta / \mathrm{MPa}^{1 / 2}$ and $19.3 \delta / \mathrm{MPa}^{1 / 2}$, respectively [11,12,18,35,37]. The closer the solubility parameter of a solvent to a substance, the stronger the softening effect of the solvent is [12,37]. Ethanol has been approved by the U.S food and drug administration (FDA,1976) as a clinically relevant food simulator [38]. MEK has been approved as a food additive by the FDA and it is naturally found in meat, yogurt, fruits and vegetables [38,39].

Several studies demonstrated a significant influence of different aging media and aging times on the mechanical properties of resin-based composites [12,26,40-42]. Hahnel and others demonstrated a significant effect of the composite materials and the storage times on the surface hardness and flexural strength; on the other hand Drummond showed a significant influence of the resin-composites and the storage media but not the storage times $[18,40]$. In the present study, there was a significant interaction between the resincomposite, storage media and the storage times $(p<0.0005)$.

The changes in the mechanical properties of resincomposite materials after aging are results of the uptake of the aging liquid in to the porosity and intermolecular spaces within the material. This uptake results in physical and chemical degradation of the material [26,43]. Physically, as the solvent diffuses in to the network system it causes

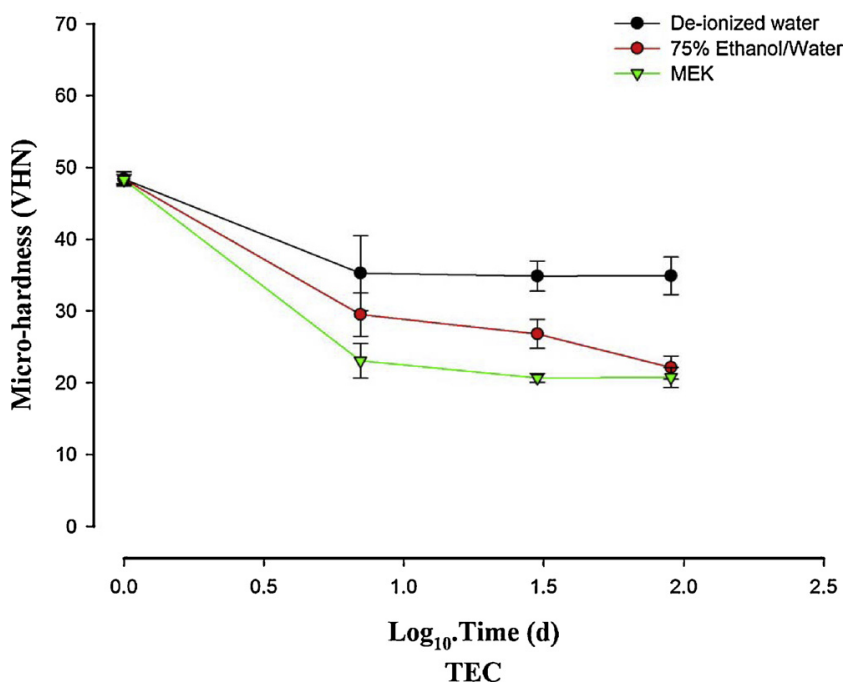

Fig. 7 - The means and standard deviations of VHN against $\log _{10}$. Time (ds) for TEC. 


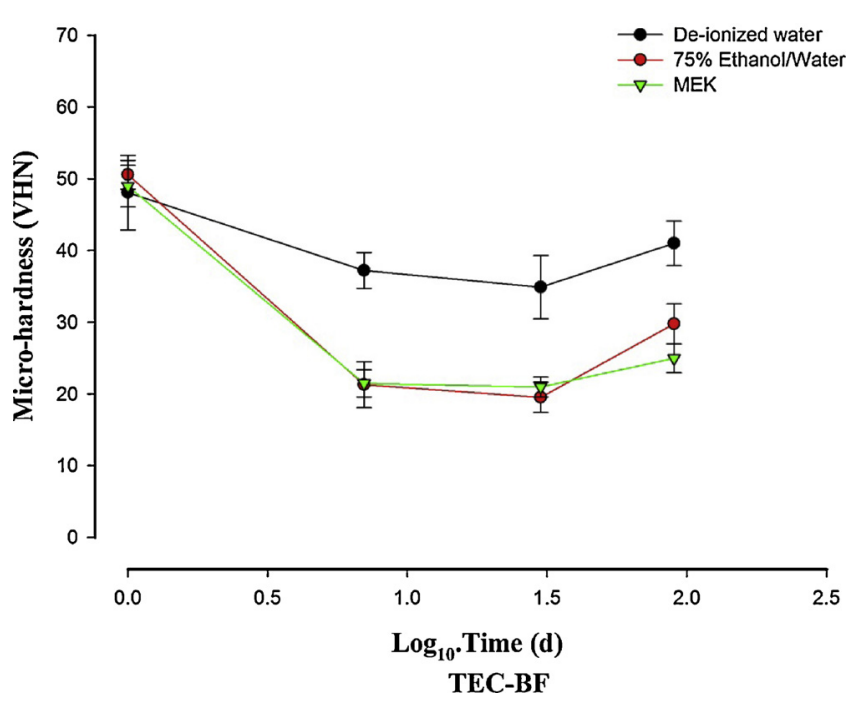

Fig. 8 - The means and standard deviations of VHN against $\log _{10}$. Time (ds) for TEC-BF.

expansion and loss of the unreacted monomers, oligomers and ions. Consequently, these solvents occupy the porosities act as plasticisers without forming any chemical bonds to the network system $[18,26]$. On the other hand, chemical degradation occurs through hydrolysis that causes changes in the polymer network microstructure and produce oligomers and monomers. Prolonged storage times can lead to pores formation within the network system through which the oligomers and monomers are lost $[18,26,44]$.

In the present study, the decrease in the VHN and DTS was more pronounced with the $75 \%$ Ethanol/water and MEK groups compared to the water stored group. The effect of water on VHN of the investigated material can be explained by the difference in the solubility parameter of the water $\left(48.0 \mathrm{\delta} / \mathrm{MPa}^{1 / 2}\right)$ compared to the resin-based materials. These results were in agreement with other studies comparing different solvents effect on resin-based composites [11,26,37,45,46].

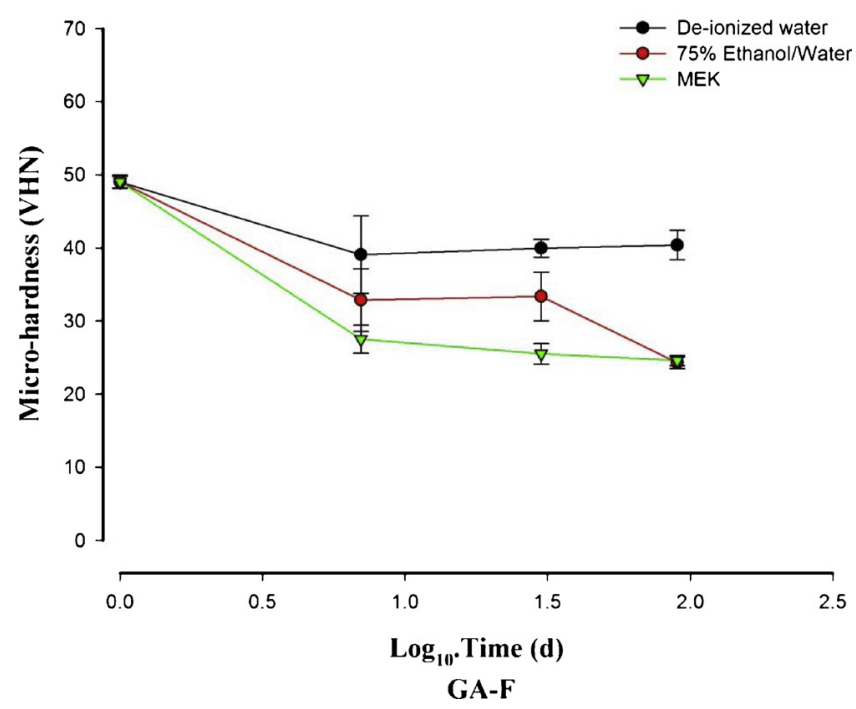

Fig. 9 - The means and standard deviations of VHN against $\log _{10}$. Time (ds) for GA-F.

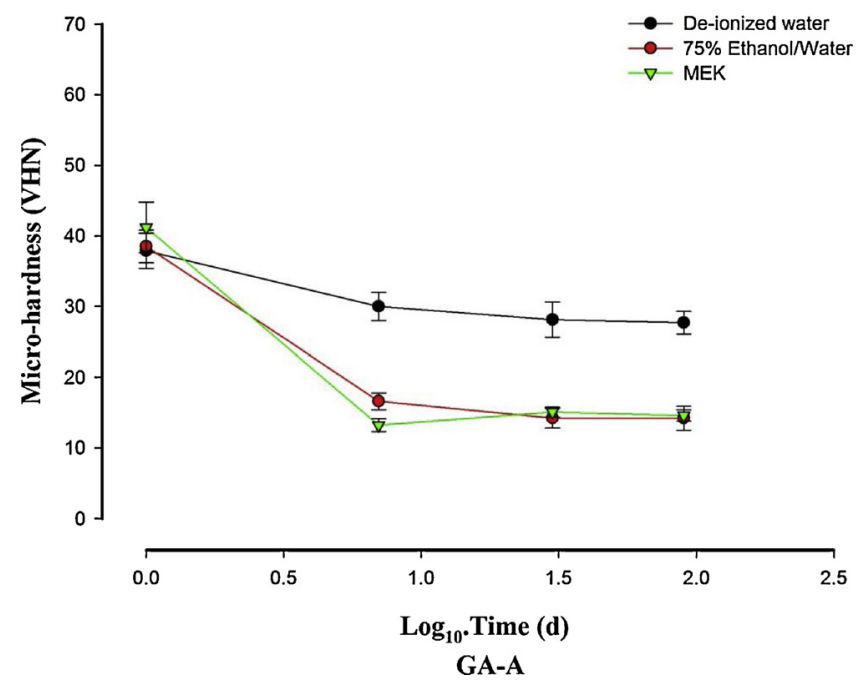

Fig. 10 - The means and standard deviations of VHN against $\log _{10}$. Time (ds) for GA-A.

Organic solvents, as Ethanol and MEK, showed more detrimental effect on the mechanical properties compared to water storage. Several studies have demonstrated more complete extraction of monomers and oligomers with the organic solvents that could explain their stronger impact on the mechanical properties [8,12,45,47-50].

In the present study, the positive correlation of VHN with the filler loading was confirmed $\left(r^{2}=0.72\right)$. This is in agreement with several studies that relate the filler loading to the surface hardness of the resin-based materials [51-55]. V-BF and SDR Bulk fill materials showed the lowest VHN and this could be explained by their low filler loading [56]. They demonstrated significant reduction in their VHN at 90d storage time that could be explained by their monomer system containing UDMA which is more prone to solvents dissolution compared to the Bis-GMA monomer [16,42-44]. Another possible reason was stated by Leprince et al. that the use of plasticizing monomers to reduce shrinkage stress with these bulk fill

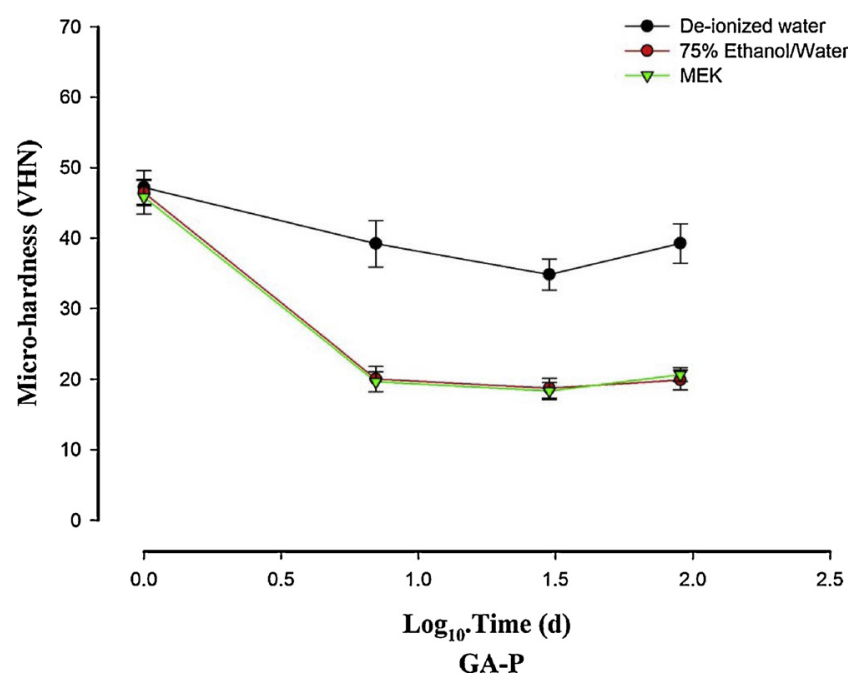

Fig. 11 - The means and standard deviations of VHN against $\log _{10}$. Time (ds) for GA-P. 

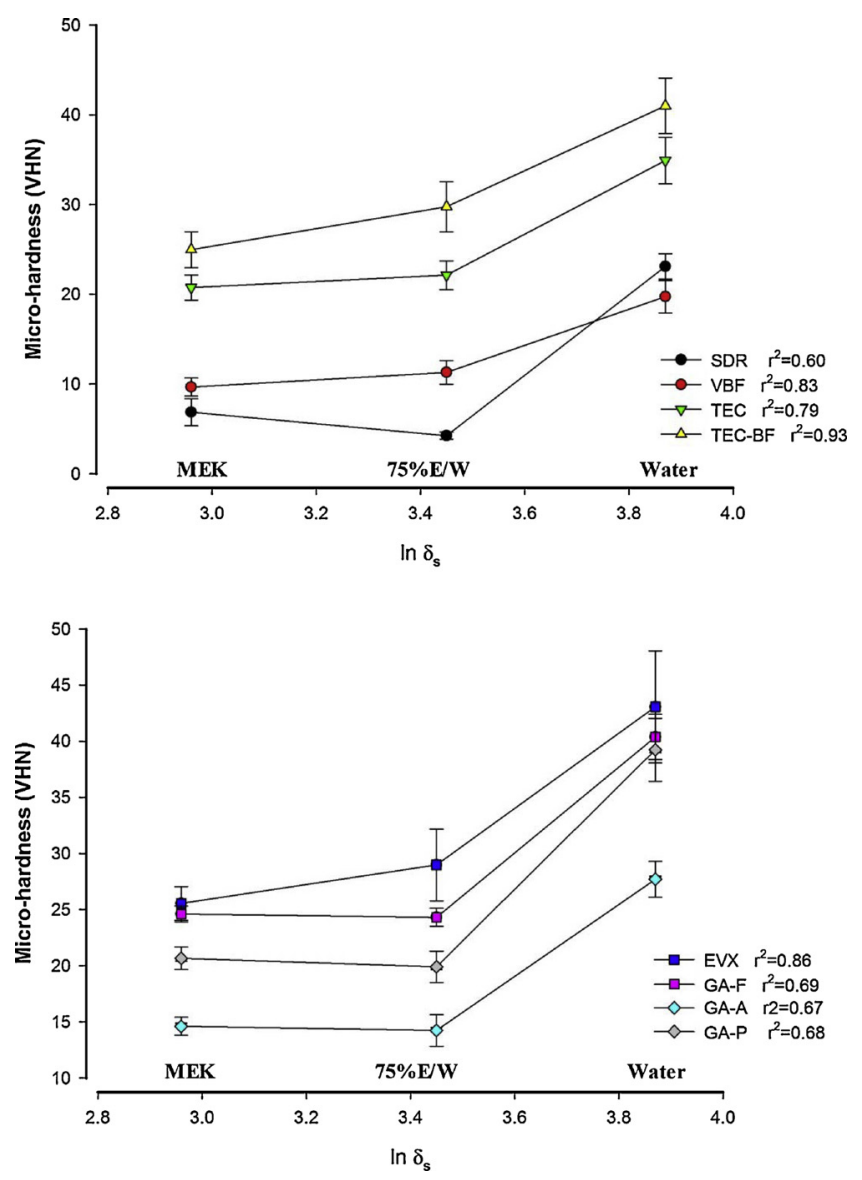

Fig. 12 - VHN of the investigated materials vs logarithmic values of solubility parameters of the solvents.

composites explains the increased softening effects by solvent storage [51].

The fibre-reinforced material investigated in this study (EVX) yielded the highest VHN at base line measurements which could be related to the short glass fibres incorporated in their filler system as this was supported by previous studies that showed a comparable increase mechanical properties compared to the other commercial composites $[57,58]$. The effect of solvents on the VHN of this material after 90 days

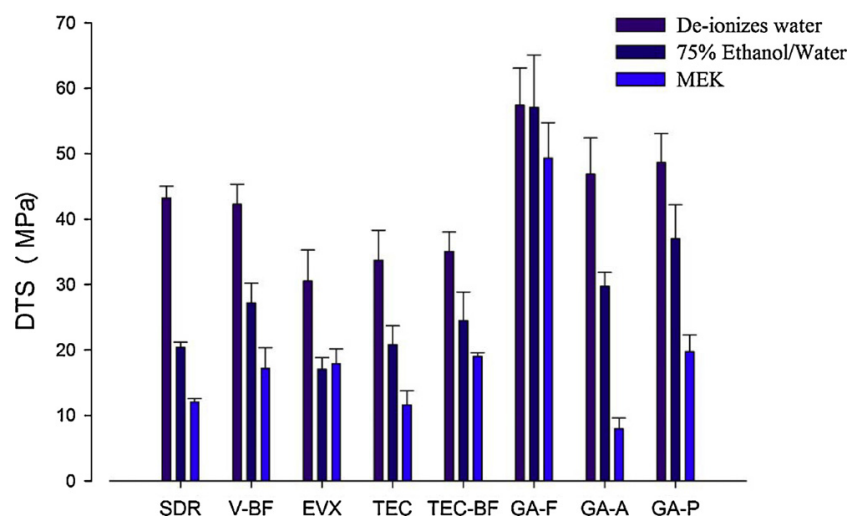

Fig. 13 - The means and standard deviations for the DTS values of the investigated materials.
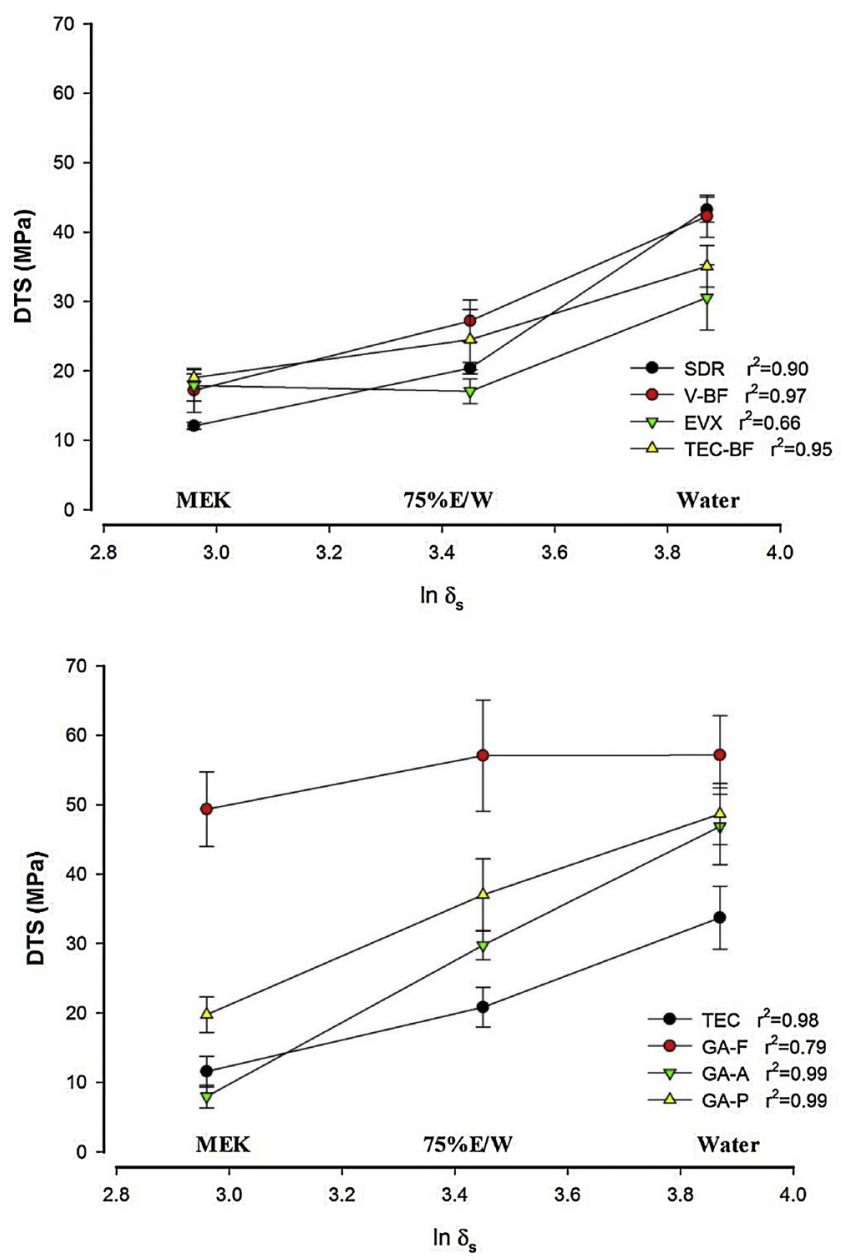

Fig. 14 - VHN of the investigated materials vs logarithmic values of solubility parameters of the solvents.

was $30 \%$ reduction in water and $51 \%$ in ethanol and $55 \%$ in MEK. This reduction in VHN can be explained by the potential deteriorative effect of solvents on the interfacial adhesion between the matrix and the glass fibres. Fibre-reinforced composites absorb more water than conventional composite, which is related to the hydrophilicity of the polymer network and the reduced stability of the filler particle in the solvent $[15,57,59,60]$.

The three nano-hybrid composites (GA-F, TEC and TEC-BF) gave high VHN values compared to the other studied materials (excluding EVX). These values can be as a result of their filler

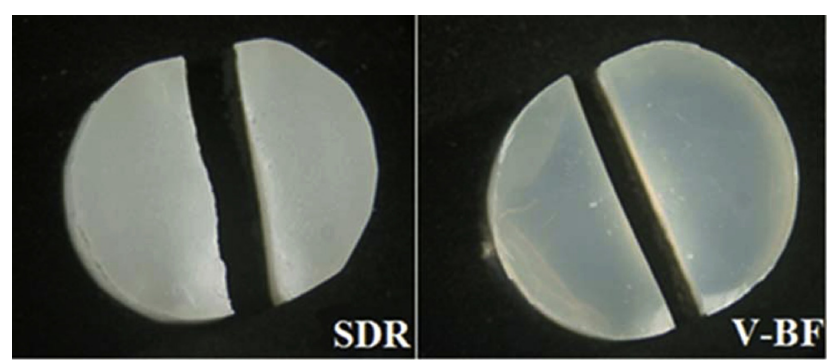

Fig. 15 - The vertical (diametral) crack after loading the specimen. 


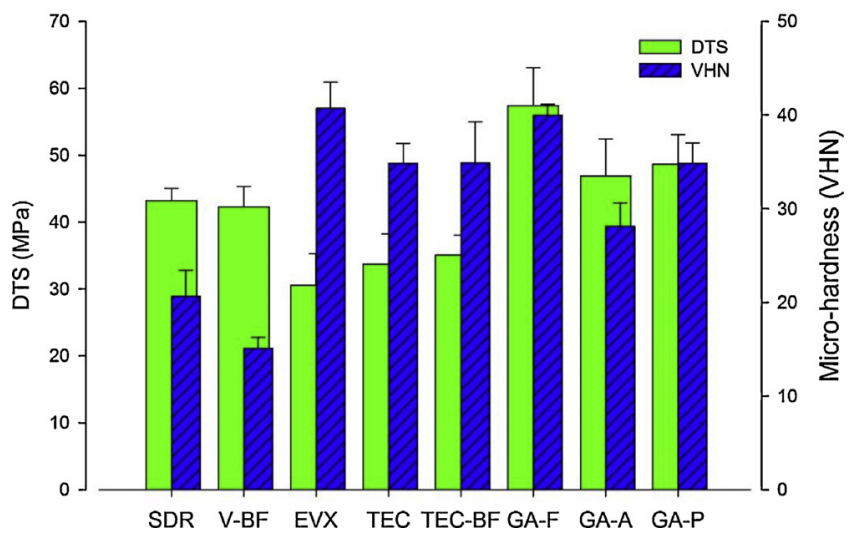

Fig. 16 - VHN of the investigated materials and DTS of the investigated materials after $30 \mathrm{ds}$ in water.

loading which ranges from 50 to $61 \%$ and the nano-sized filler particles. Nano-hybrid resin-based materials showed better mechanical properties when compared with the other materials $[61,62]$. These nano-hybrid materials showed a reduction of around $50 \%$ in $75 \%$ Ethanol/water and MEK after 90 days of storage except for TEC-BF that showed the least reduction in VHN among all the investigated materials after storage. TEC$\mathrm{BF}$ besides having camphroquinone and amine photoinitiator system, it has an initiator booster (Ivocerin ${ }^{\mathrm{TM}}$-a dibenzoyl germanium compound) that enables the material to polymerise in thicker increments $(4 \mathrm{~mm})$ [51,63-65]. Having the initiator booster in their activation system could increase the cross linking density of the cured material leading to their high resistance to solvent degradation.

The Bis-GMA free composites (GA-G and GA-P) produced a VHN that ranges from 37.89 and 47.19 , respectively. GA-A showed more VHN reduction in all storage media compared to its posterior counterpart. As both materials are having the same monomer system, the difference can be attributed to the different filler loading between the materials. This result strongly supports the positive correlation between the filler loading and surface micro-hardness [51-53,55,66].

Despite the fact that the investigated materials demonstrated significant reduction in the VHN from the base line measurements after storage, there is a slight increase that was observed for some materials at the 90 days storage time. This increase can be related to the post-irradiation polymerisation caused by the remaining free-radicals in the resin matrix. Postirradiation polymerisation is supported by the fact that the maximum degree of polymerisation needs a long period of time to be reached $[27,28,50]$.

The investigated materials showed different ranges of DTS values in each solvent. The effect of the solvents on the DTS values in this study was similar to that on the surface micro-hardness. The impact of each solvent was determined by its solubility parameter, more material degradation occurred with MEK storage followed by $75 \%$ Ethanol/water and lastly by water storage [47]. That was supported by the significant interaction found between the material type and solvent $(p<0.0005)$.
The bulk fill flowable materials, SDR and V-BF, showed significant reduction in their DTS values when stored in $75 \%$ Ethanol/water and MEK. The DTS values of SDR after storage in $75 \%$ Ethanol/water represented a $53 \%$ reduction when compared to DTS values after water storage, MEK stored samples showed even more reduced values up to $72 \%$ of the water stored DTS values. V-BF DTS values showed similar behaviour with $36 \%$ and $59 \%$ reduction after $75 \%$ Ethanol/water and MEK storage. Their low filler loading indicates high resin contents which is based on UDMA and EBADMA. UDMA-based monomer system have shown less resistance to solvent degradation compared to the BIS-GMA-based materials [41,43]. Moreover, the increased plasticity of these bulk fill materials may led to the increased softening effect of the solvents [51].

The fibre-reinforced composite, TEC and TEC-BF share the Bis-GMA monomer in their matrix system. These materials showed no significant differences in the DTS values after water storage. EVX showed no significant differences in the DTS values after 75\% Ethanol/water and MEK storage, DTS values were in the range of $17.06-17.89 \mathrm{MPa}$. The deterioration of the interface between the matrix and the filler system together with the hydrophilicity of the monomer system could explain the reduced DTS values after solvents storage $[15,57,60]$. TEC-BF demonstrated more resistance to solvent degradation, which could be related to their enhanced photoinitiation system $[51,63,66]$.

In comparing the G-aenial composites, as they share a common monomer system, the GA-F showed the highest DTS in water that might be attributed to its nano-sized filler particles compared to the other G-aenial materials tested in this study. Although GA-A and GA-P have higher filler loading (63\%-65\%, respectively) compared to GA-F (50\%) that did not result in higher DTS. This result demonstrates the very low correlation found in this study between the DTS and the filler loading. That was in accordance with other studies, as they found very low correlation between the filler loading and mechanical properties of dental resin-composites [25,67]. On the other hand, Chung et al found a clear correlation between the filler loading and the surface hardness and DTS of group of resincomposites $[54,68]$.

GA-F represents a recent generation of high viscosity flowable composites with an extended indication of larger restorations. It has been promoted for its unique consistency and comparable mechanical properties to those conventional non-flowable composites. In this study, this material showed a comparable surface micro-hardness to the other investigated materials. GA-F showed no significant difference in the DTS values in all storage media, indicating it resistance to solvent storage. These findings could be attributed to the nano-sized filler in addition to the silane treatment method that was described by the manufacturer as revolutionary in improving the material hydrolytic stability and durability [61,62].

In this study, there was no correlation found between the surface micro-hardness and the DTS values. These results is supported by other studies that found no correlation between the surface hardness and DTS values for different ranges of resin-based materials $[47,69,70]$. On the contrary, Medeiros et al. found a strong correlation between the surface hardness and the DTS values [26]. 
Notwithstanding, the complexity of the investigated material, and the resin-composites in general, makes the interpretation of the result based on an isolated factor (filler loading, filler size, filler shape and monomer system) unrealistic. Controlled systematic changes to an experimental material composition may help in full understanding the relation between the material composition and its behaviour.

\section{Conclusion}

In this study, the investigated materials represented different classes of resin-based dental composites including bulkfill, nano-hybrid, micro-hybrid and fibre-reinforced materials. They represented a range of viscosities including flowable, medium body and packable type. The results were linked to some of the materials compositional differences and the different effect of the storage media. The selection of resin-based material must be done carefully according to the clinical case requirements and conditions. The conclusions can be summarised in the following points

- The non-flowable bulk-fill materials showed comparable results with the other materials.

- Flowable bulk-fill composites showed lower surface microhardness than other bulk-fill and conventional composites.

- The significant decrease in surface micro-hardness of the flowable bulk-fill materials supports the recommendations of the manufacturers to veneer these materials.

- The type of solvent and the material composition significantly affect the extent of the resultant degradation of the material properties.

- Relationship was found between the Filler loading and the surface micro-hardness and it was not found between the DTS values of the investigated materials and their filler loading.

\section{REFERENCES}

[1] Sarrett DC. Clinical challenges and the relevance of materials testing for posterior composite restorations. Dent Mater 2005;21:9-20.

[2] Larsen IB, Freund M, Munksgaard EC. Change in surface hardness of bisgma/tegdma polymer due to enzymatic action. J Dent Res 1992;71:1851-3.

[3] Sarrett DC, Coletti DP, Peluso AR. The effects of alcoholic beverages on composite wear. Dent Mater 2000;16:62-7.

[4] Ferracane JL, Berge HX. Fracture toughness of experimental dental composites aged in ethanol. J Dent Res 1995; 74:1418-23.

[5] Atai M, Nekoomanesh M, Hashemi SA, Amani S. Physical and mechanical properties of an experimental dental composite based on a new monomer. Dent Mater 2004;20:663-8.

[6] Levartovsky S, Kuyinu E, Georgescu M, Goldstein GR. A comparison of the diametral tensile strength, the flexural strength, and the compressive strength of two new core materials to a silver alloy-reinforced glass-inomer material. J Prosthet Dent 1994;72:481-5.

[7] Ferracane JL, Condon JR. In Vitro evaluation of the marginal degradation of dental composites under simulated occlusal loading. Dent Mater 1999;15:262-7.
[8] Ferracane JL, Marker VA. Solvent degradation and reduced fracture toughness in aged composites. J Dent Res 1992;71:13-9.

[9] Tanaka J, Inoue K, Masamura H, Matsumura K, Nakai H, Inoue $\mathrm{K}$. The application of fluorinated aromatic dimethacrylates to experimental light-cured radiopaque composite resin, containing barium-borosilicate glass filler-a progress in nonwaterdegradable properties. Dent Mater J 1993;12:1-11.

[10] Calais JG, Soderholm KJM. Influence of filler type and water exposure on flexural strength of experimental composite resins. J Dent Res 1988;67:836-40.

[11] McKinney JE, Wu W. Chemical softening and wear of dental composites. J Dent Res 1985;64:1326-31.

[12] Marghalani HY, Watts DC. Viscoelastic stability of resin-composites aged in food-simulating solvents. Dent Mater 2013;29:963-70.

[13] Vandewalle KS, Ferracane JL, Hilton TJ, Erickson RL, Sakaguchi RL. Effect of energy density on properties and marginal integrity of posterior resin composite restorations. Dent Mater 2004;20:96-106.

[14] Malacarne J, Carvalho RM, De Goes MF, Svizero N, Pashley DH, Tay FR, et al. Water sorption/solubility of dental adhesive resins. Dent Mater 2006;22:973-80.

[15] Lassila LVJ, Nohrström T, Vallittu PK. The influence of short-term water storage on the flexural properties of unidirectional glass fiber-reinforced composites. Biomaterials 2002;23:2221-9.

[16] Wu W, Toth EE, Moffa JF, Ellison JA. Subsurface damage layer of in vivo worn dental composite restorations. J Dent Res 1984;63:675-80.

[17] Drummond JL. Degradation, fatigue, and failure of resin dental composite materials. J Dent Res 2008;87:710-9.

[18] Hahnel S, Henrich A, Bürgers R, Handel G, Rosentritt M. Investigation of mechanical properties of modern dental composites after artificial aging for one year. Oper Dent 2010;35:412-9.

[19] Söderholm KJ. Degradation of glass filler in experimental composites. J Dent Res 1981;60:1867-75.

[20] Cohen BI, Volovich Y, Musikant BL, Deutsch AS. Comparison of the flexural strength of six reinforced restorative materials. Gen Dent 2001;49:484-8.

[21] Craig RG, Powers JM. Restorative dental materials. 11th ed. St. Louis: Mosby; 2002.

[22] Dannheimer MF, Marais JT, Borman J, Germishuys PJ, Nel JC. Surface hardness of light-cured composite resin cured directly or through a transparent matrix using three different light guides. J Dent Assoc S Afr 1996; 51:193-5.

[23] Von Beetzen M, Li J, Nicander I, Sundström F. Microhardness and porosity of class 2 light-cured composite restorations cured with a transparent cone attached to the light-curing wand. Oper Dent 1993;18:103-9.

[24] Cho GC, Kaneko LM, Donovan TE, White SN. Diametral and compressive strength of dental core materials. J Prosthet Dent 1999;82:272-6.

[25] Johnson WW, Dhuru VB, Brantley WA. Composite microfiller content and its effect on fracture toughness and diametral tensile strength. Dent Mater 1993;9:95-8.

[26] Medeiros IS, Gomes MN, Loguercio AD, Filho LE. Diametral tensile strength and vickers hardness of a composite after storage in different solutions. J Oral Sci 2007;49:61-6.

[27] Watts DC, Amer OM, Combe EC. Surface hardness development in light-cured composites. Dent Mater 1987;3:265-9.

[28] Pilo R, Cardash HS. Post-irradiation polymerization of different anterior and posterior visible light-activated resin composites. Dent Mater 1992;8:299-304. 
[29] Lovell LG, Newman SM, Donaldson MM, Bowman CN. The effect of light intensity on double bond conversion and flexural strength of a model. Unfilled dental resin. Dent Mater 2003;19:458-65.

[30] Tarumi H, Imazato S, Ehara A, Kato S, Ebi N, Ebisu S. Post-irradiation polymerization of composites containing bis-Gma and tegdma. Dent Mater 1999;15:238-42.

[31] Söderholm KJM, Mukherjee R, Longmate J. Filler leachability of composites stored in distilled water or artificial saliva. J Dent Res 1996;75:1692-9.

[32] Schmage P, Nergiz I, Sito F, Platzer U, Rosentritt M. Wear and hardness of different core build-up materials. J Biomed Mater Res B Appl Biomater 2009;91:71-9.

[33] Baharav H, Abraham D, Cardash HS, Helft M. Effect of exposure time on the depth of polymerization of a visible light-cured composite resin. J Oral Rehab 1988;15:167-72.

[34] Price RB, Dérand T, Loney RW, Andreou P. Effect of light source and specimen thickness on the surface hardness of resin composite. Am J Dent 2002;15:47-53.

[35] Schwartz JI, Söderholm KJM. Effects of filler size, water, and alcohol on hardness and laboratory wear of dental composites. Acta Odontol Scand 2004;62:102-6.

[36] Chadwick RG, McCabe JF, Walls AWG, Storer R. The effect of storage media upon the surface microhardness and abrasion resistance of three composites. Dent Mater 1990;6:123-8.

[37] Wu W, McKinney JE. Influence of chemicals on wear of dental composites. J Dent Res 1982;61:1180-3.

[38] Food and Drug Administration. Fda guidelines for chemistry and technology requirements of indirect additive petitions. Washington, DC: FDA; 1976.

[39] Davis DM, Waters NE. An investigation into the fracture behavior of a particulate-filled bis-Gma resin. J Dent Res 1987;66:1128-33.

[40] Drummond JL, Botsis J, Zhao D, Samyn J. Fracture properties of aged and post-processed dental composites. Eur J Oral Sci 1998;106:661-6.

[41] Drummond JL, Andronova K, Al-Turki LI, Slaughter LD. Leaching and mechanical properties characterization of dental composites. J Biomed Mater Res B Appl Biomater 2004;71:172-80.

[42] Sevimay M, Yücel MT, Tak Ö. Influence of food simulating solutions on the hardness of composite resins. J Compos Mater 2008;42:69-75.

[43] Ferracane JL. Hygroscopic and hydrolytic effects in dental polymer networks. Dent Mater 2006;22:211-22.

[44] Göpferich A. Mechanisms of polymer degradation and erosion. Biomaterials 1996;17:103-14.

[45] Örtengren U, Wellendorf H, Karlsson S, Ruyter IE. Water sorption and solubility of dental composites and identification of monomers released in an aqueous environment. J Oral Rehab 2001;28:1106-15.

[46] Ferracane JL. Elution of leachable components from composites. J Oral Rehab 1994;21:441-52.

[47] Aguiar FHB, Braceiro ATB, Ambrosano GMB, Lovadino JR. Hardness and diametral tensile strength of a hybrid composite resin polymerized with different modes and immersed in ethanol or distilled water media. Dent Mater 2005;21:1098-103.

[48] Giorgi MCC, Lima DANL, Marchi GM, Ambrosano GM, Aguiar FHB. Influence of softening test and light-activation protocols on resin composite polymer structure. Eur J Dent 2014;8:9-14.

[49] Rathbun MA, Craig RG, Hanks CT, Filisko FE. Cytotoxicity of a Bis-Gma dental composite before and after Leaching in organic solvents. J Biomed Mater Res 1991;25:443-57.

[50] Alshali RZ, Salim NA, Satterthwaite JD, Silikas N. Post-irradiation hardness development, chemical softening, and thermal stability of bulk-fill and conventional resin-composites. J Dent 2015;43:209-18.
[51] Leprince JG, Palin WM, Vanacker J, Sabbagh J, Devaux J, Leloup G. Physico-mechanical characteristics of commercially available bulk-fill composites. J Dent 2014;42:993-1000.

[52] Ilie N, Hickel R. Investigations on a methacrylate-based flowable composite based on the Sdr (Tm) technology. Dent Mater 2011;27:348-55.

[53] Leprince J, Palin WM, Mullier T, Devaux J, Vreven J, Leloup G. Investigating filler morphology and mechanical properties of new low-shrinkage resin composite types. J Oral Rehab 2010;37:364-76.

[54] Chung KH, Greener EH. Correlation between degree of conversion, filler concentration and mechanical properties of posterior composite resins. J Oral Rehab 1990;17:487-94.

[55] Sudheer V, Manjunath MK. Contemporary curing profiles: study of effectiveness of cure and polymerization shrinkage of composite resins: an in vitro study. J Conserv Dent 2011;14:383-6.

[56] Flury S, Hayoz S, Peutzfeldt A, Hüsler J, Lussi A. Depth of cure of resin composites: is the Iso 4049 method suitable for bulk fill materials? Dent Mater 2012;28:521-8.

[57] Garoushi S, Vallittu PK, Lassila LVJ. Short glass fiber reinforced restorative composite resin with semi-inter penetrating polymer network matrix. Dent Mater 2007;23:1356-62.

[58] Garoushi S, Vallittu PK, Lassila LVJ. Depth of cure and surface microhardness of experimental short fiber-reinforced composite. Acta Odontol Scand 2008;66:38-42.

[59] Vallittu PK. Effect of 180-week water storage on the flexural properties of E-Glass and silica fiber acrylic resin composite. Int J Prosthod 2000;13:334-9.

[60] Abdel-Magid B, Ziaee S, Gass K, Schneider M. The combined effects of load, moisture and temperature on the properties of E-glass/epoxy composites. Compos Struct 2005;71: 320-6.

[61] Papadogiannis DY, Lakes RS, Papadogiannis Y, Palaghias G, Helvatjoglu-Antoniades M. The effect of temperature on the viscoelastic properties of nano-hybrid composites. Dent Mater 2008;24:257-66.

[62] Mitra SB, Wu D, Holmes BN. An application of nanotechnology in advanced dental materials. J Am Dent Assoc 2003;134:1382-90.

[63] Ilie N, Bucuta S, Draenert M. Bulk-fill resin-based composites: an in vitro assessment of their mechanical performance. Oper Dent 2013;38:618-25.

[64] Randolph LD, Palin WM, Bebelman S, Devaux J, Gallez B, Leloup G, et al. Ultra-fast light-curing resin composite with increased conversion and reduced monomer elution. Dent Mater 2014;30:594-604.

[65] Randolph LD, Palin WM, Watts DC, Genet M, Devaux J, Leloup G, et al. The effect of ultra-fast photopolymerisation of experimental composites on shrinkage stress, network formation and pulpal temperature rise. Dent Mater 2014;30:1280-9.

[66] Alrahlah A, Silikas N, Watts DC. Post-cure depth of cure of bulk fill dental resin-composites. Dent Mater 2014;30:149-54

[67] Ilie N, Hickel R. Investigations on mechanical behaviour of dental composites. Clin Oral Investig 2009;13:427-38.

[68] Chung KH. The relationship between composition and properties of posterior resin composites. J Dent Res 1990;69:852-6.

[69] Harrison A, Draughn RA. Abrasive wear, tensile strength, and hardness of dental composite resins-Is there a relationship? J Prosthodont 1976;36:395-8.

[70] Moraes RR, Gonçalves LS, Lancellotti AC, Consani S, Correr-Sobrinho L, Sinhoreti MA. Nanohybrid resin composites: nanofiller loaded materials or traditional microhybrid resins? Oper Dent 2009;34:551-7. 